\title{
SCHREBER'S SOUL-VOLUPTUOUSNESS: MYSTICISM, MADNESS AND THE FEMININE IN SCHREBER'S MEMOIRS
}

\author{
BRENT DEAN ROBBINS \\ Duquesne University
}

\begin{abstract}
Freud's 1911 case study based on Schreber's (1903) Memoirs of My Nervous Illness provides the investigator with the opportunity to reexamine Freud's interpretation through a return to the original data Freud used. This study reveals both the insights and limitations of Freud's theory of paranoia. An alternative interpretation of the case is offered from an existential-phenomenological perspective which aims both to expand upon and transform Freud's study without negating its value. Freud draws on the mythologies of the sun to argue for his hypothesis that the "father-complex" lies behind Schreber's God. By following some of the many other mythological themes in Schreber's memoirs, Freud's interpretation is opened to a larger, socially and historically situated context. An examination of cross-cultural and historical studies of mystical experience shows how Schreber's psychosis is simultaneously a form of madness and spiritual breakthrough. Schreber's is viewed as a narcissistic experience of the infant-child in which the imaginal has been exiled from rational, modern adulthood and is inaccessible to Cartesian language. Instead of recognizing the soul-full world of "miracles," Schreber envisions the absorption of the entire world into himself and he thus becomes an inflated caricature of the "heroic ego" at its extreme.
\end{abstract}

In 1911, Freud published a case study based on Dr. Schreber's (1903) Memoirs of My Nervous Illness. This case study provides the investigator with the unique opportunity to reexamine Freud's interpretation through a return to the original data of Schreber's text. The Schreber case study is the only case by Freud in which we have access to the exact same source of data he used to reach his conclusions. In telling Schreber's story, I present Freud's interpretation of Schreber, as well as his motives for interpreting the memoirs, in order to show both the insights and limitations of his theory of paranoia. In turn, I offer an alternative interpretation of Schreber from an existential-phenomenological perspective which aims both to expand upon and transform Freud's theory and interpretation without negating its value. 
Freud draws on the mythologies of the sun to argue for his hypothesis that the "father-complex" lies behind Schreber's God. However, Freud restricted his exploration of mythological themes to this one example. In following the many mythological themes in Schreber's memoirs, one can open Freud's interpretation to a larger, socially and historically situated context. Doing so, it becomes possible to reexamine Freud's notion of paranoia as a regression to narcissism via a return to Schreber's text. Through an examination of cross-cultural and cross-historical studies of mystical experience, Schreber's psychosis can be viewed as both madness and spiritual breakthrough.

When Schreber felt his body brimming with "soul-voluptiousness," he experienced the eruption of the sensual, lived world which had been repressed, along with the imaginal, with the Cartesian worldview. Schreber's experience is the narcissistic experience of the infant-child in the sense that it is in the experience of the infant-child that the flesh of sensuality has been exiled from the rational, modern adult. Schreber's madness results from his Cartesian language, which prevents him from speaking of his experience in words that are adequate for the task. Instead of a recognition of the soul-full world he comes to experience through "miracles," Schreber instead envisions the absorption of all the world into him, and thus becomes the inflated stereotype of the "heroic ego" at its extreme.

It is significant that Schreber describes the emergence of his "soulvoluptuousness" as a process of "unmanning." Schreber's description of his "unmanning" can be understood as part of his prophetic message to the world that something is amiss in the "order of the world." In both theological and social spheres, he can be seen, despite his madness, to be already anticipating 20th century movements such as feminism and more earth-based religious sensibilities. By prophetically demonstrating the benefits of the "unmanning" of our culture, Schreber can be understood as struggling to overcome the limits of existence in his age that have been identified and addressed by others 'less mad' in time. Such a reading of Schreber's memoirs respects its insights with regard to truth and justice rather than simply dismissing them from the order of the world.

\section{Freud's Methods and Motives in his STUdy OF SGHREBER}

In 1911, Freud published his case study of Dr. jr. Daniel Paul Schreber, "Psychoanalytic Notes Upon an Autobiographical Account of a Case of Paranoia (Dementia Paranoides)." Unlike Freud's previous case studies, this study was based on a person's own account of his condition, the 
autobiography of Dr. Schreber (1903), Memoirs of My Nervous Illness. Freud's previous case studies, on the contrary, were developed from his own notes on patients he had seen in therapy. The one exception to this rule was the case of "little Hans," in which Freud played a secondary role, reading the notes of the boy's father who, in turn, implemented Freud's advice (Freud, 1909a). But even in this case Freud was able to watch the temporal unfolding of the child's case as it occurred, and, further, intervened in the case along the way. Schreber's memoirs, however, provided Freud with a unique challenge.

First, Freud was faced with the problem that Schreber's memoirs were incomplete. Due to the possibility of libel suits, Schreber's editor had eliminated large amounts of information from the original text (Schreber, 1903). Much to Freud's chagrin, these censored sections largely included information regarding Schreber's family history. Second, despite the missing information, Freud was faced with the perhaps more problematic task of illuminating the unconscious conflicts which, for Freud, must have lead to the onset of Schreber's mental illness. Nevertheless, Freud justified his attempt to interpret Schreber as follows: "The psychoanalytic investigation of paranoia would be altogether impossible if the patients themselves did not possess the peculiarity of betraying (in a distorted form, it is true) precisely those things which other neurotics keep hidden as a secret" (Freud, 1911, p. 83).

Freud seems to be aware of his limitations, yet he justifies his belief that an interpretation of Schreber's case will be valuable by arguing that the world of the psychotic is almost completely (though in distorted form) transparent to the observer. What would be repressed in the neurotic, Freud argues, is right there, out in the open, with the psychotic. Yet, this argument seems to beg the question. If Freud is using Schreber as a case to defend his theory of psychotic paranoia, which he claims to be doing, how can he make this a priori claim? In the latter portion of this paper, we can understand in what sense Freud encountered a "truth" of psychosis with this claim, but he unfortunately fails here to justify his assertion regarding the transparency of the psychotic's world.

Unfortunately, Freud never truly elaborates on how his method of approaching Schreber's text differs from his previous case studies. In Studies on Hysteria (1895) Freud at first used hypnosis to reveal the origin of the patient's symptom. Later, having found that he was a poor hypnotist, he used what he called the "pressure technique" instead. In his case study of "Miss Lucy R.," Freud describes this technique:

I decided to start with the assumption that my patients knew everything that was of any pathogenic significance and that it was only a question 
of obliging them to communicate it. Thus when I reached a point at which, after asking a patient some question such as: "How long have you had this symptom?" or: "What was its origin?", I was met with the answer: "I really don't know," I preceded as follows. I placed my hand on the patient's forehead or took her hands between my hands and said: "You will think of it under the pressure of my hand. At the moment at which I relax my pressure you will see something in front of you or something will come into your head. Catch hold of it. It will be what we are looking for. Well, what have you seen or what has occurred to you?". (Freud, 1895, p. 110)

With this pressure technique, later to be abandoned in favor of the instruction that the patient "free associate," Freud was led to discover the importance of "resistance." Where a patient distorts his or her story, Freud understood this to mean that he had found an access to the patient's "unconscious" conflict(s) which brought about the symptom; that is, the patient's conscious "resisted" the memory of the past "unconscious" trauma. Freud's first mention of "resistance" appears in his case study of "Fraulein Elisabeth von R.," where he began to note the times when it became particularly difficult, using the "pressure technique," to uncover her memories (Freud, 1895).

This discovery of "resistance" led Freud (1895) to the conclusion that "by means of psychical work" he "had to overcome a psychical force in the patient which was opposed to the pathogenic ideas becoming conscious (being remembered)" (Freud, 1895, p. 268). Further, this "resistance" stems from the nature of past trauma, which is "of a distressing nature, calculated to arouse the effects of shame, of self-reproach, and of psychical pain, and the feeling of being harmed" (Freud, 1895, p. 269). The patient's "resistance" amounted to a form of "defence" against the psychical pain associated with the past traumatic event. Finally, when the patient's "resistance" could be overcome, the unconscious contents were brought to light to serve in the interests of the patient's cure (Freud, 1904).

Freud, in analyzing Schreber's memoirs, obviously does not intend to "cure" Schreber, nor could he do so merely by examining the man's autobiography. Schreber is not Freud's patient. Yet, in his analysis of Schreber's memoirs, this is perhaps Freud's biggest obstacle of all. Since Schreber is not in psychoanalysis with Freud, their relationship is inevitably one-sided. Freud is unable to use either the "pressure technique" or the method of "free association" to discover Schreber's unconscious traumas. Therefore, Freud is unable to truly examine Schreber's "resistance." Freud nevertheless claims this does not matter in the case of the paranoid, since he or she has no "secrets." The implication is that 
he need only to explore the manifest content of the memoirs to uncover Schreber's implicitly revealed history from which his madness erupts. This will be important to keep in mind as we examine Freud's interpretation of Schreber.

The one-sidedness of Freud's relationship to Schreber, who is revealed through his text rather than in therapy, leads to another important problem for Freud. Freud often relies on the patient's reactions to his interpretations in order to judge their accuracy. This is evident, for example, in the case of the "Wolf Man," whereby Freud (1918) made suggestions, which in turn opened up new associations for the patient. Freud judges the accuracy of his interpretation based on the degree to which the patient becomes more open to the associations in the preconscious leading toward the unconscious trauma. Yet Freud is deprived of this technique with Schreber.

In psychotherapy, Freud also listens for ambiguous phrases and gaps in the patient's stories as signposts leading toward repressed memories. In the case of "Dora," for example, Freud focuses on the phrase, "Something might happen at night," in order to disclose Dora's unconscious associations relating to repressed memories of Herr K., bedwetting and her father (Freud, 1905). Unlike the above-mentioned methods of investigation, this method is a promising approach for Freud in his analysis of Schreber. As we shall see, it is one of the primary methods of investigation he uses throughout his interpretation of the case. Nevertheless, Freud is deprived of the satisfaction of witnessing Schreber's reactions to these interpretations. Further, he is precluded from eliciting from Schreber pre-conscious memories and associations with these gaps and ambiguities which might otherwise have disclosed Schreber's unconscious history. For these reasons, Freud maintains a sense of ambivalence toward the conclusion of his study, recognizing his limitations.

With all of these obstacles, as well as others I may have failed to mention, why would Freud bother with interpreting Schreber's case at all? What is Freud's motive for this task? As Chabot (1982) writes: "Freud's enthusiasm for Memoirs resides chiefly in the opportunity the volume affords him to present a segment of his evolving psychologythe theory of paranoia - to the psychoanalytic community" (p. 108). Like Chabot, I tend toward the conclusion that Freud's interpretation of Schreber's case provides him with a widely publicized case of paranoia with which to present his theory of paranoia to his audience. Further, Freud had already developed his theory of paranoia, and this afforded him the opportunity to "test" his theory against an actual case. Macalpine and Hunter (1955), translators and editors of Schreber's 
memoirs, suggest that "Freud's attention had been drawn to Schreber's memoirs by Bleuler," since they were both co-editors, with Jung, of Fahrbuch Fur Psychoanalytische und Psychopatholohische Forschungen, "a binannual publication started in 1909 and discontinued in 1912," in which Freud's study of Schreber's case first appeared (p. 10). At the time, Bleuler was interested in utilizing Freud's ideas to enlarge upon the pathology of "dementia praecox," which Kraepelin had originated (p. 9). In any case, Freud did not approach Schreber's case empty handed. He had already developed a theory of paranoia which certainly guided his hand in his interpretation of Schreber. Whether Freud fully "bracketed" his theory of "paranoia" in order to view Schreber's memoirs from a fresh perspective is left to history to decide. History has arrived.

In the case of Freud's study of Schreber, we are given the privilege of examining Freud's approach to a case study by a return to the original data of Schreber's text. In fact, Schreber's case is the only case study of Freud's which provides this opportunity. Freud, for reasons unknown to this investigator, destroyed all the notes which he'd written during analysis with his patients. The only notes which have survived are those of Freud's (1909b) analysis of Paul Lorenz, a.k.a. the "Rat Man," which also provides an opportunity for examiners to study Freud's method of investigation via a source at least somewhat closer to Freud's. Yet, even in the case of Lorenz, the examiner does not have access to the same source as Freud. One is still required to remain bound to those instances which Freud deemed important enough to transcribe into his notes. Yet, this is not a problem with Schreber. The very same memoirs which Freud used to develop his description and interpretation of Schreber is available to anyone curious enough to hunt down a copy and read.

\section{SGHREBER'S STORY}

Before embarking on a description and critique of Freud's interpretation of Schreber's memoirs, it is necessary to provide a brief summary of Schreber's story. The memoirs are as lengthy and as tedious as they are fascinating to read. In the end, it is truly worthy material for an analysis, and scholarly study is certainly in line with at least one of Schreber's intentions for writing the memoirs. Schreber felt that "expert examination" of his body and observations of his personal fate would be "of value for science and the knowledge of religious truths" (Schreber, 1903, p. iii).

Prior to the onset of his "nervous illness" as described in his memoirs, Schreber had been admitted to an asylum for severe hypochon- 
dria. Eight years later, he first developed the symptoms of schizophrenia, the experience of which he accounts in the memoirs. Schreber's age at the time of his "nervous illness" is not revealed in the memoirs. However, Freud (1911), based on information provided by a physician in Dresden, placed the year of his birth in 1842. It has been reported that Schreber never fully recovered from his "illness" and was admitted to an asylum for the third time in 1907, where he died in 1911. The antecedent of this third "illness" has been reported to be the death of his wife (Macalpine \& Hunter, 1955). However, this information remains unconfirmed.

Below, I have developed a time line which marks the major events in Schreber's life from the time of the onset of his hypochondriasis to his reported death:

1884 (Autumn): Onset of "hypochondriasis," for which Schreber is admitted to the Psychiatric Clinic of Leipzig, as the patient of Professor Paul Emil Flechsig.

1885 (June): Full recovery from "hypochondriasis." Released from asylum.

1885 (Winter): Resumed position as Judge at the County Court of Leipzig, one of five Governmental Districts into which Saxony was divided.

1886-1893: Reported as being "happy" with his wife, although disappointed that he and his wife were unable to bear children. That is, his wife suffered from "six spontaneous miscarriages" (Chabot, 1982, p. 17).

1893 (June): Notified of his prospective appointment as Senatspräsident of Dresden.

1893 (Late summer): Had several dreams in which he dreamt that his "hypochondriasis" had returned. On one of these occasions, he was revolted by the thought which occurred to him, between a state of being awake and asleep, "that after all it really must be very nice to be a woman submitting to the act of copulation" (Schreber, 1903, p. 36).

1893 (Early October): Took up duties as Senatspräsident.

1893 (Late October): Suffered a severe onset of insomnia. Voluntarily returned to Flechsig's asylum, where he subsequently developed a return of the "hypochondriasis" and displayed the first signs of ideas of "persecution" (Schreber, 1903).

1894 (perhaps March or April): According the Schreber, "a plot was laid against me,... the purpose of which was to hand me over to another human being after my nervous illness had been recognized 
as, or assumed to be, incurable, in such a way that my soul was handed to him, but my body-transformed into a female body and, misconstruing the ... fundamental tendency of the Order of the World - was left to that human being for sexual misuse and simply 'forsaken,' in other words left to rot" (Schreber, 1903, p. 75).

1894 (June): Schreber transferred from Flechsig's Clinic to Lindenhof, Dr. Pierson's Private Asylum, a.k.a. "Devil's Kitchen," in Coswig near Dresden. Shortly thereafter, he was again transferred to Sonnenstein Asylum in Pirna, also near Dresden, "the first German Public Mental Hospital" (Schreber, 1903, p. 3).

1895 (November): Schreber made a profound change in regard to his feeling that he had been going through a process of "unmanning," in which he was "maliciously" being transformed into a woman. During this time, writes Schreber (1903): "the signs of transformation into a woman became so marked on my body, that I could no longer ignore the imminent goal at which the whole development was aiming ... Soul-voluptuousness had become so strong that I myself received the impression of a female body, first on my arms and hands, later on my legs, bosom, buttocks and other parts of my body" (p. 148). In turn, Schreber felt that "nothing was left" to him but to "reconcile" himself "to the thought of being transformed into a woman" (p. 148). Therefore, rather than resist the process of "unmanning," Schreber began the attempt to speed up this process by, for example, "picturing" his body as being of the female form (p. 180).

1899: Dr. Weber, Schreber's physician at the time, reported that Schreber's condition had significantly improved, such that "an observer who was uninstructed upon his general condition would scarcely notice anything peculiar..." Yet, continued Weber, he remained "full of ideas of a pathological origin" (Schreber, 1903, p. 386). Also, Schreber reportedly first learned that he had been temporarily placed under tutelage as early as 1895. In turn, he "approached the authorities demanding a decision as to whether the temporary tutelage was to be made permanent or whether it could be rescinded" (Schreber, 1903, p. 5).

1900: Schreber's "whole body" was "filled with nerves of voluptiousness" which, he claimed, were visibly apparent to observers. He took to wearing female adornments to assist his achievement of "voluptuousness." Schreber began to write his memoirs and began the process of achieving legal independence from tutelage. A formal order for his tutelage was made by the district court of Dresden.

1901 (July): Schreber appeared to be further along in his recov- 
ery by admitting that the people around him were "real" rather than "cursory contraptions" (Schreber, 1903, p. 409). Also, tutelage was confirmed by the Court. In response, Schreber appealed to the Superior Court in Dresden, the highest Appeal Court in Saxony.

1902 (September): Schreber succeeded in having his tutelage rescinded in the Court of Appeal.

1902 (December): Schreber wrote the preface to his memoirs. He stated his intention to leave the asylum by 1903 .

1903 (March): Schreber had left the asylum. He wrote his "Open Letter" to Professor Flechsig, which is contained in the preface of the memoirs. The memoirs were published later this year.

1907: Schreber reportedly returned to an asylum for the third time following the death of his wife.

1911: Schreber's reported year of death, at the age of 60. Cause of death is unknown.

It is convenient to view Schreber's life according to three phases of temporal development. First, there is the time prior to the onset of his second "nervous illness," before 1893. Since the impetus for Schreber's illness appears to have been his appointment as Senatspräsident of Dresden, the summer of 1893 marks the beginning of his second phase. His experience of his illness profoundly changed in November of 1895. The beginning of these changes seems to have been facilitated by his transfer to Sonnestein, where he was placed under the care of Dr. Weber. Therefore, one can mark the beginning of Schreber's third phase in the summer of 1894, when he was transferred from Dr. Pierson's asylum.

Prior to the onset of his second "nervous illness," Schreber led a life filled with successes and career triumphs, offset by the inability of he and his wife to bear children. Shortly after his appointment as Judge of the County Court of Dresden, Schreber suffered his first attack of "hypochondriasis." As the patient of Professor Emil Flechsig, Schreber was admitted to the Psychiatric Clinic of the University of Leipzig. Flechsig would later care for Schreber during the first two years of his second "nervous illness," and would, in turn, come to play a primary role in Schreber's belief that a conspiracy to commit "soul murder" had been laid against him.

Although, according to Schreber, his "first illness passed without any occurrences bordering on the supernatural," his experiences at this time set the stage for his later illness (p. 62). On the one hand, Schreber said he had developed "favorable impressions of Professor Flechsig's methods of treatment." However, he felt strongly that Flechsig had commited 
perhaps "indispensable," "white lies" against him, specifically by attributing his illness "solely to poisoning by potassium bromide" (p. 62). He felt his cure could have been hastened and that Flechsig had not adequately concerned himself over his loss of weight. Nevertheless, writes Schreber, he "had at the time no reason to be other than most grateful" to Flechsig for ultimately curing him of his ailments, at least for the time being (p. 63). Schreber's wife, however, appeared to be less ambivalent about Flechsig's care for her husband, owing to the fact that "she kept his picture on her desk for many years" (Schreber, 1903, p. 63).

Between the time of his first and second illness (1884-1893), Schreber's wife suffered from "six spontaneous miscarriages," no doubt leading to Schreber's eventual resignation to the fact that he and his wife would be unable to bear children (Chabot, 1982, p. 17). This "repeated disappointment" for Schreber was paralleled by eight relatively happy years with his wife, "rich also in outward honors"-which culminated in his eventual appointment to Senatspräsident of Dresden, the zenith of Schreber's meteoric rise through the Saxony judicial system (Schreber, 1903, p. 63). Ironically, Schreber's career would also lead to the conditions which would shortly thereafter result in his second illness, for which he would be institutionalized for the majority of his remaining years.

Between the time of his appointment to Senatspräsident and the taking up of his duties of this office, Schreber was disturbed by the recurring dream that his hypochondriasis had returned. On one of these occasions, in a state of consciousness between wake and sleep, Schreber was struck by an idea which he deemed "highly peculiar"- "the idea that it really must be rather pleasant to be a woman succumbing to intercourse" (Schreber, 1903, p. 63). This thought of Schreber's would prove to be a premonition of sorts, for he would later become convinced that a conspiracy had been arranged to turn his body into a woman's through a process he called "unmanning." Even at this early stage, Schreber did not "exclude the possibility that some external influences were at work to implant" the idea in him (p. 63).

Two-three months after possessing this "peculiar idea," Schreber took office as Senatspräsident on October 1st of 1893. Schreber immediately found himself overcome by a "heavy burden of work" even as he was "driven ... to achieve ... the necessary respect" of his colleagues, many of whom were older and more experienced than he (Schreber, 1903, pp. 63-64). Even as he was faced with this daunting task, Schreber succumbed to a severe bout of insomnia "at the very moment" when he "was able to feel that [he] had largely mastered the difficulties" of his new position (p. 63). Schreber's debilitating sleeplessness led him again 
to seek the care of Flechsig. Even before his admission to Flechsig's clinic, he had already begun to develop the suspicion that "miracles" were at work in his suffering. That is, he felt that "right from the beginning the more or less definite intention existed to prevent [his] sleep" (p. 64). Precisely who was behind these "miracles" became the subject of Schreber's laborious thought process throughout his second illness as he persisted in his effort to discover the responsible parties for his torments. As a result of this process, Schreber finally developed an elaborately designed theological framework with which to justify his beliefs. These ideas evolved through the rest of his life and were eventually chronicled in his memoirs. Throughout his memoirs, Flechsig remained a prominent figure as a responsible party in the conspiracy to commit "soul murder" against him, although Flechsig's role remained dynamic, changing according to Schreber's latest collection of "evidence."

From the beginning, Schreber admits to a difficulty in translating his experiences to language, as well as the irrefutability of all that he presents in the memoirs:

I cannot of course count upon being fully understood because these things are dealt with which cannot be expressed in human language; they exceed human understanding. Nor can I maintain that everything is irrefutably certain even for me: much remains only presumption and probability. After all I too am only a human being and therefore limited by the confines of human understanding; but one thing I am certain of, namely that I have come infinitely closer to the truth than human beings who have not received divine revelation. (Schreber, 1903, p. 41)

In turn, Schreber warns the reader that, in order to make his "supernatural" experiences comprehensible, he must use "images and similes, which may at times perhaps be only approximately correct" (p. 41). Throughout the memoirs, Schreber points to Biblical texts and natural science to support the "evidence" for his "supernatural" experiences, often amending current theories and beliefs according to his own experiences.

During the second phase of Schreber's story, Flechsig plays the central role in the conspiracy against Schreber to "murder" his "soul." Schreber's concept of "soul murder" remains vague throughout his memoirs, but he exerts much effort in making this intelligible to the reader. In the beginning, he explains that his relationship to Flechsig must have begun with their ancestors dating back to the 18th century, at which time one of Flechsig's ancestors attempted "soul murder" against a distant relative of his. Schreber, therefore, feels that his relationship to Flechsig carries on a legacy which culminates in his persecution by Flechsig's soul. Throughout his memoirs, Schreber remains undecided 
as to whether the "actual" Flechsig is or was ever intentionally involved in his persecution. However, he conjectures that Flechsig may have lost a portion of his soul, which in turn haunts him. In any case, Schreber contends that the idea of "soul murder" is "widespread in the folk-lore and poetry of all peoples, that it is somehow possible to take possession of another's soul in order to prolong one's life at another soul's expense, or to secure some advantage which outlasts death" (p. 55). That a portion of Flechsig's soul could torment Schreber's person without the "actual" Flechsig knowing is given explanation by Schreber by way of his elaborate theological explanations.

Schreber contends that the "human soul" is "contained in the nerves of the body" (p. 45). While a person is living, these "nerves" provide the connection between his or her body and soul, enabling the person to "retain the memory of impressions received" and giving him or her the "power to move muscles" through "exertion of their will power" (p. 45). Schreber also concludes that God is "only nerve" or all soul and therefore has no body, and that He is "infinite" while human beings have "limited" nerves. The "essence of creation," thus, involves God's ability to transform His "nerves" into living beings through "rays" (p. 46). Further, Schreber comes to believe that God finished His creation of the world when He succeeded in creating human beings. Upon His creation of human beings, God withdrew from the world so that "as a rule" $\mathrm{He}$ "did not interfere directly in the fate of peoples or individuals" (p. 48). This sustains Schreber's belief that human beings have "free will" and that their souls can be "blackened" by bad deeds or "sins." Schreber thus concludes that God and human beings have no contact until a human being dies, at which time a person's "nerves" or soul re-unites with God's "infinite" nerves. The exception to this rule are those souls which are too "blackened" and therefore rejected by God.

Since Schreber does not believe there is such a thing as hell or eternal damnation, he believes that "blackened" souls are purified by unknown means. Souls which are in the process of being purified in such a way are called "tested souls." Schreber concludes that Flechsig's soul is actually a "tested soul" which intends to transform him into a woman. Doing so, Schreber believes, will cause his soul to experience "highgrade excitation" with which "tested souls" may experience a feeling of bliss similar to those souls which have already united with God's soul in a "state of Blessedness" ("uninterrupted enjoyment combined with the contemplation of God") (p. 49). Thereby, Schreber confirms his belief that Flechsig commits soul murder against him by using his soul for his own purposes, and, in turn, provides Flechsig with a motive for his alleged conspiracy against him. 
Schreber theorizes that Flechsig's ancestors had somehow been granted "contact with divine nerves," as he explains:

It seems very probable that contact with divine nerves was granted to a person who specialized in nervous illnesses, partly because he would be expected to be a highly intellectual person, partly because everything concerning human nerves must be of particular interest to God, starting with his instructive knowledge that an increase in nervousness among men could endanger his realms. (Schreber, 1903, p. 56)

Schreber goes on to conclude that an ancestor of Flechsig had, upon receiving such contact, abused his privilege, thereby placing the universe in jeopardy by offending the "Order of the World" (p. 56). For Schreber comes to believe that, upon God's withdrawal from the human state of affairs, there had developed, apart from God, the "Order of the World" with its own laws and systems of justice. Schreber reasons that there is "no clash of interests between God and human beings as long as" their relationship is in "accordance with the Order of the World" (p. 60). Since this relationship had been violated, "all creation" is at risk (p. 60).

Even from the beginning, Schreber does not place the fault of the conspiracy against him squarely upon the shoulders of Flechsig or his ancestors. He suspects from the start that God Himself was a co-conspirator, if not the instigator of the entire affair (p. 77). Towards the latter half of his illness, after he was moved to Sonnenstein, Schreber felt that God had seen him as a threat due to his "nervousness." Such a "high-grade nervousness," he decided, has a compelling nature to God, who is attracted by the "soul-voluptuousness." Being so, God draws nearer to the world, which He feels is a threat to His existence, for the possibility of being absorbed into Schreber's nerves!

Originally, God and the co-conspirators had attempted to "unman" him by transforming him into a woman. As Schreber explains:

Always the main idea... was to "forsake" me, that is to say abandon me; at the time I am now discussing it was thought that this could be achieved by unmanning me and allowing my body to be prostituted like that of a female harlot, sometimes also by killing me and later by destroying my reason (making me demented). (Schreber, 1903, p. 99)

Unfortunately for God, the "unmanning" procedure had the opposite effect he intended. That is, God, through "divine rays," began "the gradual filling of [Schreber's] body with nerves of voluptuousness (female nerves)" which had the "reverse effect" (p. 99). Instead of Schreber being "abandoned" through this process, his resulting "soul-voluptuousness" actually developed an "increased power of attraction" for 
God (p. 99). In turn, God was forced to develop other means to protect Himself, through either killing Schreber or destroying his reason. Through various "miracles" via "divine rays," Schreber experiences a whole host of physical and mental torments. In particular, the "rays" develop a variety of means to prevent him from either sleeping or defecating/urinating, which increases his "soul-voluptuousness." Schreber supports this notion with the documentation of many actual incidents which happened to him along the way. He documents these experiences in painstaking detail, and they are incredibly fascinating to read.

In June of 1894, Schreber was transferred from Flechsig's clinic to Lindenhof, Dr. Pierson's asylum, which Schreber came to call "Devil's Kitchen." At this time, the senior attendant of the asylum, "von W." also became, like Flechsig, a primary character in his story. According to Schreber, the "tested souls" of Flechsig and von W. were mutually involved in the organization of a larger party of "tested souls" who systematically tortured him by attacking various regions of his body, particularly his head in order to destroy his reason. Also, Schreber had become convinced that, due to the violation of the "Order of the World," the world had actually come to an end, so that no actual persons remained alive. Instead, the people Schreber encountered came to be understood as "fleeting-improvised-men" who were manifestations of "divine rays" sent to torment him. Schreber describes his experiences in "Devil's Kitchen" as involving the most extravagant displays of miracles of all. Throughout his brief stay at this asylum, Schreber's body was systematically destroyed piece by piece in order to fill his body with female nerves.

After his brief stay in "Devil's Kitchen," Schreber was again transferred; this time, to Sonnestein Asylum in Pirna, near Dresden, where he was placed under the care of Dr. Weber. Schreber divides his experience at Sonnenstein into two periods, the first of which he describes as "holy" and "awesome" and the second as "more and more ordinary" (p. 114). It was also here at Sonnenstein that Schreber's experience of his nervous illness took a radical turn, for which it can be understood as a third phase in Schreber's history. In the memoirs, this turn of events is preceded by a visit from Schreber's wife, who brought him a poem she had written, ending with the verse: "Then comes to you a faithful guest/God's still and silent peace" (p. 116). Schreber interpreted the words "God's peace" as "the expression used in the basic language for sleep produced by divine rays," due to which he understood his wife to be expressing the words "let me" in the basic language, meaning: "Let me-you rays that are turning me back-do 
let me follow the power of attraction of my husband's nerves: I am preparing to dissolve in my husband's body" (p. 116).

Following this experience, Schreber came to develop the notion that he could save the world by reconciling God and the "Order of the World" through the process of "unmanning." In essence, he felt that his transformation into a woman, by eliciting extreme "soul-voluptuousness," would attract all those blackened, tested souls into his own nerves, eliminating them "from their position of so-called middle instances" between himself and "God's omnipotence" (p. 117). Upon removing these tested souls from their position he could become impregnated by God "with the purpose of creating new human beings" (p. 117). In turn, "a solution of the conflict in consonance with the Order of the World would follow automatically," leading to his "cure by a complete calming of [his] nerves through sleep" (p. 117). As a result, Schreber began to see the process of "unmanning" as a duty to God. He writes:

... the Order of the World imperiously demanded my unmanning, whether I personally liked it or not, and that therefore it was common sense that nothing was left to me but reconcile myself to the thought of being transformed into a woman. (Schreber, 1903, p. 148)

Schreber started to believe that the "Order of the World" was on his side, and thus he could not lose. He concludes that, ultimately, he will win the favor of God, who will come to understand the inevitability of his triumph. Further, due to the violation of the "Order of the World," the "divine rays" had not been used for their "essential purpose," which is not "to fight an individual human being and work destruction on his body," but instead "to create" (p. 184).

Schreber divides God into two personages, an "upper God (Ormuzd)" and a "lower God (Ariman)" (p. 53). The names "Ormuzd" and "Ariman" are derived from the Avestic or Zoroastrian religion of the Ancient Iranians and modern Parsees, although Schreber makes no other explicit allusions to this religious system. "Ormuzd" is the title given to the Zoroastrian god, also known as Anro-Mainyus, the Good Spirit, while "Ariman" or "Ahriman," typically called Ahura Mazda, is the Evil Spirit. The connection of Schreber's system to Zoroastrianism is unclear, and he does not appear to divide these two gods into good and evil. Rather, the lower God, who is closer to the world, is the one who first begins to understand Schreber's value, and as a result welcomes the bliss of Schreber's soul-voluptuousness. In time, as the upper God also draws nearer to the world, He too comes to understand the power of Schreber's unmanning to restore the "Order of the World." Schreber testifies that, 
as a result, he experienced "spontaneous generation" all around him. He understands "spontaneous generation" to be "creation through divine miracles," which had begun to occur for the first time in thousands of years (p. 191). For when God had at first withdrawn to "an enormous distance," He left the "Order of the World" of human beings with free will to fend for itself (p. 191). Yet, as God draws closer, according to Schreber, the world is again filled with miracles (p. 196).

As Schreber's soul-voluptuousness attracted all of the tested souls into his ever-more-sensuous body, he experienced this as "little men" who, for a time, danced among his body parts, only to eventually absorb into him. Flechsig and von W. also became "little men." In order to preserve themselves, these tested souls resorted to a process Schreber calls "mechanical fastening" or "tying-to-celestial bodies" by which they cling to celestial bodies in order to prevent their absorption into him. By the end of 1897, "von W.'s soul eventually disappeared altogether unnoticed" by Schreber (p. 157). Flechsig's soul remained "a meager remnant (tied on to somewhere)," but which had:

... long ago lost its intelligence, that is to say it is now also totally devoid of thoughts, so that it can hardly even enjoy with satisfaction its own heavenly existence, which it had unlawfully achieved against God's omnipotence - and this once again represents one of the most glowing confirmations of the Order of the World, according to which nothing can maintain itself permanently which contradicts it. (Schreber, 1903, p. 158)

Thus, Schreber, a man of justice, found in his story an understanding of a friendly universe with its own built-in sense of justice, the "Order of the World." He found a meaning in his suffering: Nothing less than the salvation of the universe. In the meantime, he took to various devices in order to speed up the process of unmanning, such as "picturing" himself as a female in his "mind's eye" and wearing female adornments (p. 180).

By 1899, Dr. Weber reported that Schreber's condition had significantly improved, such that "an observer who was uninstructed upon his general condition would scarcely notice anything peculiar." Yet, continued Weber, he remained "full of ideas of a pathological origin" (p. 386). It was at this time, incidently, that Schreber first learned he had been temporarily placed under tutelage as early as 1895, and so "approached the authorities demanding a decision as to whether the temporary tutelage was to be made permanent or whether it could be rescinded" (p. 5). In 1900, Schreber began to write his memoirs while beginning the process of achieving his legal independence. In 1902, Schreber suc- 
ceeded in having his tutelage rescinded in the Court of Appeal, and, subsequently, in March of 1903, he left the asylum to be with his wife until her death. So, according to the memoirs, goes the story of one Daniel Paul Schreber's "nervous illness."

\section{Freud's Interpretation OF SGhreber And THEORY OF PARANOIA}

Freud reveals his intent in interpreting Schreber's story as follows:

The psychoanalyst, in the light of his knowledge of the psychoneurosis, approaches the subject with a suspicion that even mental structures so extraordinary as these and so remote from our common modes of thought are nevertheless derived from the most general and comprehensible human impulses; and he would be glad to discover the motives of such a transformation as well as the manner in which it has been accomplished. With this aim in view, he will be eager to go more deeply into the details of his delusion and into the history of its development. (Freud, 1911, p. 93)

Freud will therefore interpret Schreber's story in light of his theory of paranoia. First, Freud points out that Schreber's medical report stresses two points: Schreber's role as "Redeemer" and his transformation into a woman. For Freud, the latter is the primary delusion, which is "only later transformed into a religious delusion of grandeur" (p. 94). Further, Freud argues that at first God is Schreber's ally rather than an accomplice in the conspiracy against him and that Flechsig and von W. are from the beginning understood as the subjects of his persecution. Freud's interpretation is not entirely accurate here, because God is originally an adversary for Schreber and only later does he come to believe that God is an ally. Here, Freud seems to conveniently misread Schreber's memoirs on a point that will support his theory of paranoia. Freud appears to be correct, however, in that Flechsig is viewed as a conspirator from the very beginning. Freud also points out the inherent irony of Schreber's religious thought: "Before [his illness] he had been inclined to sexual asceticism and had been a doubter in regard to God; while after it he was a believer in God and a devotee to sensual pleasure" (Freud, 1911, p. 107). With these points in mind, Freud proceeds with his interpretation.

What techniques/methods does Freud use? As mentioned above, he has a difficult task on his hands. He is unable to gauge the effectiveness of his interpretation based on Schreber's response. Further, when Freud finds gaps and ambiguities in the text, he cannot probe deeper into Schreber pre-conscious associations through "free association" to discover 
further information. Finally, Freud lacks the means to delve into Schreber's past family history to discover childhood experiences which may have led to his illness. What is left for Freud to do? He writes:

... we have only to follow our usual psychoanalytic technique (to strip his sentence of its negative form, to his example as being the actual thing, or his quotation or gloss as being the original source) and we find ourselves in possession of what we are looking for - a translation of the paranoic mode of expression into the normal one. (Freud, 1911, p. 110)

Following this technique, Freud arrives at the conclusion that Schreber's illness was the result of his repressed homosexuality. First, Freud goes back to Schreber's recurrent dreams of hypochondria and his thought upon waking "that after all it really must be very nice to be a woman submitting to the act of copulation" (Schreber, 1903, p. 36). Freud explains that Schreber experiences the dreams and the thought in "immediate succession," therefore the dream of the return of the hypochondriasis roused in his mind the thought of his former physician, Flechsig. As a result, Freud concludes, "the feminine attitude which he assumed in the fantasy [thought] was primarily directed towards the physician" (Freud, 1911, p. 118). Thus, the "exciting cause of illness" for Schreber was an "outburst of homosexual libido" (p. 118).

Freud goes on to provide further evidence in favor of his argument. For example, he notices that Schreber's illness at Flechsig's asylum took a turn for the worse when his wife went on vacation, thereby leaving him unprotected "against the attractive power of the men about him" (p. 121). As Schreber's physician, Flechsig became an object of Schreber's "homosexual libido" by virtue of transference. Yet, why did Schreber see Flechsig as his persecutor? To explain this, Freud sets up the opportunity to present his theory of paranoia. Because of the defense mechanism of reaction formation, Schreber's love for Flechsig became transformed into hate for him for persecuting him. Further, with the defense of projection, Schreber then began to experience Flechsig as hating him, thereby keeping his repressed homosexual feeling at a protective distance.

Why then does Schreber go on to create an elaborate theological explanation for his suffering in which God becomes the primary persecutor, as well as his salvation? Freud argues that "it was impossible for Schreber to become reconciled to playing the part of a female prostitute towards his physician," and thus the role of Flechsig became replaced by God, who "called up no such resistance on the part of his ego" (p. 123). Through his idea of God as the recipient of his soulvoluptuousness, Schreber is able to turn what might otherwise be viewed 
as a disgrace into a "great cosmic chain of events ... instrumental in the re-creation of humanity after its extinction" (p. 124). Further, by his idea of creating a "new race of men," Schreber was also able to live out his fantasy of bearing children, which he was incapable of doing with his wife. Therefore, says Freud, Schreber's "ego found compensation in his megalomania, while his feminine wish-fantasy gained its ascendancy and became acceptable" (p. 124). Finally, "the struggle and the illness could cease" (p. 124).

Freud also took this interpretation a step further by suggesting that, behind the figures of God and Flechsig, Schreber held repressed homosexual feelings toward other persons whom he had loved; namely, his father and brother, respectively (p. 127). Freud supports this contention in various ways. For example, he argues that Schreber's vision of the sun, which he identifies with God, is a symbol for the father, and so reveals a "father complex." That is, "his father's most dreaded threat, castration, actually provided material for his wish-fantasy (at first resisted but later accepted) of being transformed into a woman" (p. 131).

In his theory of paranoia, Freud portrays the paranoid schizophrenic as "fixated" at the stage of narcissism, between the stages of auto-eroticism and object-love, in the development of the libido. The paranoid schizophrenic, according to Freud, experiences a regression to this stage of narcissism wherein the person withdraws his or her "libidinal cathexis" from the world (p. 146). In fact, Freud argues that the formation of delusions, the symptom of paranoid schizophrenia by which we recognize its pathology, is "in reality an attempt at recovery, a process of reconstruction" (p. 146). In the case of Schreber, Freud recognizes the withdrawal of "libidinal cathexis" in Schreber's experience of the end of the world, which he interprets as "the projection of his inner catastrophe; for his subjective world has come to an end since he had withdrawn his love from it" (p. 146). It follows that Schreber's attempt to save the world is truly an attempt to return his love to the world.

In the final analysis, Freud admits that he had "purposely restricted [himself] to a minimum interpretation" (p. 157). After reading the richly complex and textured memoir of Schreber, one is likely to feel somewhat disappointed by Freud's treatment of the case. In reading Freud's essay, one does not get the feel of a continuous, cohesive whole, such as with his case study of "Rat Man" or "Wolf Man," for example. Freud leaves many loose ends untied, although he admits his treatment of Schreber's memoirs is indeed limited in scope. Freud scratches the surface of the memoirs just enough to provide support for his theory of paranoia and leaves it behind. 
In the postscript of his study of Schreber, Freud pays homage to his close colleague at the time, Carl Jung, with whom he was still amiable. Freud (1911) writes:

... Jung had excellent grounds for his assertion that the mythopoetic forces of mankind are extinct, but that to this very day they give rise in the neurosis to the same psychological products as in the remotest past ages... [T] $[\mathrm{T}$ same holds good of the forces that work the formation of religions. (p. 159)

Schreber's memoirs are steeped in mythological themes and images. The memoir is not simply a story of a man's delusions, but a story of Schreber's developing religious convictions, which he attempts to communicate to his audience, despite language barriers, with support from his experiences, as well as from theology and science. Freud draws on the mythologies of the sun in order to argue for his hypothesis that behind Schreber's God lies his "father-complex." Thus, Freud, as he was sometimes led to do (usually as a last resort), interprets the case of Schreber by virtue of the mythological heritage associated with those symbols which weave the contextual web which binds Schreber's religion to his largely unconscious, cultural history. In his postscript, Freud admits to the restrictedness of his interpretation, no doubt realizing the complex tapestry of mythological images laid down by Schreber in the memoirs. To offer up a more total, holistic interpretation of Schreber's mythological world is beyond Freud's scope.

\section{A Different Approagh to Understanding Sihreber}

To take a different approach to understanding Schreber means to read Schreber in a different way, to use a different method. But what method? With Lothane (1993), a method which truly attempts to comprehend Schreber must be "informed by the ethics of love and love of Schreber... on his terms, based on the oxymoron that love makes one see more clearly than scientific detachment" (p. 4). One can easily read Schreber's text with clinical distance and simply write him off as deranged and unusual. Yet read with love, Schreber can come alive again as a person who lived, suffered and triumphed, and with a certain level of empathic engagement, we can imagine what it must have been like to be him in his own time, struggling for his freedom. We will never possess Schreber and know him in any totalizing way, but the sheer volume of literature dedicated to the man over the years is a testament to the fact that his story lives on. He still touches us.

At the same time, a method of love for Schreber is in itself necessary but not sufficient. Love can dissolve into sentimentality, and we 
run the risk of idealizing Schreber to the detriment of validating the depth of his suffering in his madness. Many, such as Szasz (1997), would see Schreber's madness as merely manufactured by the psychiatric industry. While there is a certain truth to the sentiments of such anti-psychiatry, I believe it misses the importance of recognizing and validating Schreber's "psychopathology," the logos of his pathos, which speaks in his symptoms. The truly difficult task of reading Schreber is to hold the tension between understanding him as a prophet, poet and judge, on the one hand, and as a psychotic madman, on the other. To hold such a tension, one runs the risk of portraying Schreber as mere madman, yet it also opens the possibility for seeing the prophecy, poetry and sense of justice in his madness rather than buying into the common sense notion that madness is the antithesis of such virtues.

To hold the tension between Schreber as poet-visionary and as madman requires a particular orientation to madness: an orientation that acknowledges his difference. To simply brand Schreber as "mentally ill" is to cast him in the role of other and totalize him as such. Yet to acknowledge Schreber in his difference is to remain open to what his madness has to teach us about his difference. As Heidegger (1971) writes:

... the madman. Does the word mean someone who is mentally ill? No. Madness [Wahnsinn] here does not mean a mind filled with senseless delusions. "Whan" belongs to the old high German wana and means: without. The madman's mind senses - senses in fact as no one else does. Even so, he does not have the senses of others. He is of another mind. "Sinnan" signifies originally: to travel, to strive for ..., to drive in a direction; indogermanic root sent and set means way. The departed one is a man apart, a madman, because he is on the way in another way. From that other direction, his madness may be called "gentle," for his mind pursues a greater stillness. (p. 173)

The primary thesis of this interpretation of Schreber holds that it is Schreber's difference as a psychotic that opens him to other ways of being that are otherwise closed off to those of us who are socially considered "sane." As Laing (1969) acknowledged, "sanity or psychosis is tested by the degree of conjunction or disjunction between two persons where the one is sane by common consent" (p. 36). Schreber's disjunction from what is "sane" by "common consent" is precisely what permits him to discover, at the limits of reason in his age, other ways of being. Being otherwise, Schreber unfortunately suffers, and suffers no doubt from the felt loneliness of his disjunction from those "fleeting-improvised men" he encounters along the way. As van den Berg (1972) observes, it is such loneliness which is "the central core" of madness, for "the psychiatric patient stands apart from the rest of the world" (p. 105). 
Freud's method, in contrast, is not a method which acknowledges Schreber's difference. Rather, his method, as Freud himself states, is "a translation of the paranoic mode of expression into the normal one" (Freud, 1911, p. 110). What could Freud mean by the "normal" mode of expression? Based on Freud's analysis, what he considers to be the normal mode of expression is his own theoretical language with which he had already articulated his theory of paranoia. By using his method of negation, by which he negates Schreber's words, he arrives at the conclusion that Schreber, after all, fits into his already formulated theory. As mentioned previously, Freud even goes to the lengths of distorting Schreber's story to better fit his theory. By claiming that God was originally viewed by Schreber as an ally, while Flechsig and von W. are seen as adversaries, Freud helps support his theory that Schreber's delusions regarding God are a defense against homosexual impulses toward his physicians. Yet one need only read the memoirs to discover that this is not the case.

Freud's agenda, which is to use Schreber to present his theory of paranoia to the psychoanalytic community, is not the best method to use if one wants to allow Schreber to speak on his own terms. While Freud states his case, Schreber is not there to provide the voice necessary to confirm or invalidate his claims. Yet while Scheber is no longer here to validate our claims, we have his text which speaks to us. Out of love for Schreber and with the desire to validate the logos of his pathos, it is possible to read the letter of his memoirs as closely as possible so that, in his difference, he can reveal his being otherwise to us. Having taken up this task, at least upon one reading of Schreber's text, we can discover that he, almost a century ago, had already given voice to a being otherwise which others, less mad, would also speak and, so doing, change the world. For this task, it is necessary to resist, as much as possible, the temptation to totalize Schreber with our theories. Instead, we must allow Schreber's being otherwise to disrupt the totality of our self-same existence so that we might hear what he has to teach us.

There are generally two approaches to reading Schreber's text so that he might teach us. For one, we can look at his interpersonal relationships with others: his wife, Flechsig, von W., etc. To observe his descriptions of his experience of others, we can read his delusions, not as mere distortions, but as having an existential truth. Also, we can engage Schreber's text on a more broader, cultural level in order to both understand his "illness" as situated within a social-historical world and discover what he has to teach us about our cultural-historical epoch. From this more global perspective, while always already situated in time and 
not above it, we can begin to thematize what was still latent in Schreber's text: 1) the cultural-historical world in which he lives and in which his memoirs are a constituent in the larger whole, and 2) that which for Schreber was to come, but which we, years later, are now living. Namely, Schreber can teach us about how his madness (and the madness which he shares with others like him) is itself a cultural-historical event. Further, we can discover with Schreber how his experience in madness, by which he suffered, also opened up new possibilities for being religious and for being gendered which others, in time, have also explored, perhaps with less suffering and less stifling solitude.

That Schreber can be both mad and visionary is less unseemly when viewed in light of other cultures. For example, we can look to the tales of Cader Idris, the high mountain of North Wales. According to Celtic tradition, those who traveled there and spent the night were destined either to die, go mad, or become a visionary poet (Freeman, 1998). Those Celts who survived the trip to Cader Idris became known as filidh, a title which means both "seer" and "poet." The word derives from the root, "to see," and, to the Celts, vision and poetry go hand in hand. He served as "a mediator between the supernatural powers and the human race," and thus served as a kind of shaman. The job of the filidh was to see beyond the world of convention, to bring back imbas, the "knowledge which enlightens" as a gift from "the god that kindles fire in the head" (p. 29).

To read Schreber's memoirs, the parallels between his experience and those of the shaman are not at all far-fetched. For example, Schreber talks of his body being destroyed piece by piece, as he is simultaneously resurrected in the body of a woman. Schreber's "end of the world" does, as Freud (1909) adeptly discovers, parallel with the dissolution of his physical and mental being, which occurs in his story at the time of catatonic withdrawal. Silverman (1967) has pointed out that schizophrenic experience, not just Schreber's, finds parallels in the experience of shaman in preindustrial hunting peoples. In early adolescence, the young shaman undergoes a crisis of experience in which he or she undergoes an experience of being physically torn to shreds, and, retreating into a world of frightening visions, returns to the world with a message for his or her community. Yet, as Silverman writes: "In primitive cultures in which such a unique crisis resolution is tolerated, the abnormal experience (shamanism) is typically beneficial for the individual, cognitively and affectively; he [or she] is regarded as one with expanded consciousness" (p. 210). In modern culture, there are very few places for such an experience. The person undergoing such an experience is 
provided few cultural signposts and helpful others to guide him or her along the way. Unlike the shaman, who is prepared for his or her "journey" via the ritualized songs, dances and stories of his or her culture, as well as by elders who are there for guidance, the modern schizophrenic is ostracized, often drugged, and left to his or her devicesoften with the result that the schizophrenic remains caught in the horrific experience of mental and physical disintegration that, for the shaman, is only a temporary passage to a new way of being.

That Schreber, largely on his own, was able to find his way back from his own crisis is a testament to his strength, integrity and, above all, hope that what he was experiencing was not for nothing. Schreber's effort throughout the rest of his stay at Sonnenstein, and even after his release from this asylum, involves a restoration of his world. Freud argues that the "Reedemer" myth is secondary to Schreber's story. He wishes to argue that Schreber's role as "Redeemer" follows from his desire to be a woman; that to be bear children with God masks his desire to make love to his father. Yet Freud's evidence for Scheber's homosexual desire for his father is lacking, and his argument that the sun symbolizes the God which stands in for Schreber's father is quite an interpretive leap. Schreber, after all, is not homosexual, but rather a man who wants to be "unmanned." Gender identity issues are typically not directly associated with homosexuality. While this interpretation fits Freud's theory, it closes off another, more central issue: Schreber's desire for justice, for that is the central theme of his life. Schreber, appointed to the highest judicial position in Saxony, had dedicated his life to the pursuit of justice: the "Order of the World." Shortly upon being granted this prestigious position, he suffered his second attack of "nervous illness." Bearing the weight of responsibility for this task, he cracked. By his efforts to become Orderer of the World, Schreber simultaneously restores his own world, his very being.

Also, given that there are no explicit references that Schreber's God is a symbol for his father-or, for that matter, is a defense against anything, homosexuality or otherwise - there really is no justification for reducing Schreber's religious system to mere symptoms. That Freud makes such an interpretation is even more suspect since it contradicts his statement that Schreber's memoirs can be read on the surface. If Schreber's God really represented his father, this would be a psychic defense mechanism (displacement) which would assume some degree of neurotic repression. If so, Freud appears to contradict himself, since he claims Schreber's text is to be read differently from that of the neurotic. Even if we made the case that such a defense is more "primitive" than neurotic defenses, the only way Freud is able to justify his 
interpretation is by making the assumption that God always symbolizes one's actual father. Why not simply allow Schreber's God to be God?

It is possible to read Schreber's religiosity, not as a mere symptom of psychopathology, but as a genuine spiritual urge. Schreber's religious system does not appear any more pathological than any other religious system. One could certainly make the claim that all religious systems are pathological, but that does little to distinguish Schreber's religiosity from any other religiosity. There is a decided advantage in accepting Schreber's religiosity as a genuine spiritual urge. It then becomes possible to understand his psychosis as, in part, spiritually revelatory, perhaps even prophetically so, as an opening onto a different kind of religiosity.

Campbell (1972) writes that "the imagery of schizophrenic fantasy perfectly matches that of the mythological hero journey" (p. 208). He continues:

The usual pattern is, first, of a break away or departure from the local social order and context; next, a long, deep retreat inward and backward, as it were, in time, and inward, deep into the psyche; a chaotic series of encounters there, darkly terrifying experiences, and presently (if the victim is fortunate) encounters of a centering kind, fulfilling, harmonizing, giving new courage; and then finally, in such fortunate cases, a return journey of rebirth to life. And that is the universal formula also of the mythological hero journey, which I, in my own published work, had described as: 1) separation, 2) initiation, and 3) return. (Campbell, 1972, pp. 208-209)

Campbell's map of the hero's journey of separation, initiation and return matches Schreber's story in an uncanny way. Schreber's "journey" involves many kinds of separation. He becomes separated from the world of his home life and powerful position as judge. Further, he separates from the world in his catatonic retreat from those around him, who become as "fleeting-improvised men." $\mathrm{He}$ is then initiated upon the quest to restore balance to the slighted "Order of the World," which he feels will be accomplished when he is transformed into a woman. This moment, when Schreber comes to recognize the meaning of his suffering (the logos of his pathos) as a function of his personal quest, his condition takes a vital turn. He sees the goal at the end of his mission and is therefore able to plot his return. Schreber's schizophrenic experience, like Silverman's description of the shaman and the experience of the filidh in Celtic tradition, unmistakably follows the pattern of Campbell's "hero journey." There are many kinds of hero journeys, but Schreber's seems to share many similarities with the experience of the mystic. 
As James (1961) shows, the mystic is left by the wayside in modernism. The "mystical" is now a term used for "mere reproach, to throw at any opinion which we regard as vague and vast and sentimental, and without base in either facts or logic" (p. 299). Like Campbell's description of the hero journey, James' "four marks" of the mystic also sheds light on Schreber's experience. And why shouldn't it, if as James (1961) writes: "personal religious experience has its root and centre in mystical states of consciousness" (p. 299)? Schreber's experience bears the mark of "ineffability," for he must struggle to find a way to express his experience in the limited language of his culture. Further, Schreber's experience expresses the "noetic quality" of the mystic, for his story is full of "illuminations" and "revelations, full of significance, all inarticulate though they remain" (James, 1961, p. 300). Next, Schreber's experience meets the criteria of "transiency," for he cannot sustain his "soul-voluptuousness" for long, and, unless compelled to think compulsively, his God withdraws. Finally, Schreber experiences the mystic's "passivity" in which he "feels as if his own will [is] in abeyance."

While recognizing Schreber's experience as having mystical qualities, we must also resist romanticizing Schreber or anyone who has or will have the experience of the schizophrenic. For Schreber suffers, like all shamans and mystics suffer, but he suffers doubly so, for his people do not have the ears to hear his message, nor does he have the cultural and interpersonal support to provide an intelligibility for his experience. Schreber's experience, in the context of modern culture, is an experience of a madman. Schreber is blazingly mad! As Laing (1967) acknowledges, one cannot separate the person labeled with the "condition" of "schizophrenia" from the context of his or her culture and social situation: The "label is a social fact and the social fact a political event" (p. 121).

The social context which enables a person to be "labeled" schizophrenic eludes Freud. It has been the task of those who have followed in his footsteps. Yet, if one takes Heidegger seriously, one can perform a genuine act of history with the work of Freud to wrest from his work a past which opens up future possibilities. In this case, Freud traces paranoid schizophrenia back to a point of "fixation" at the stage of "narcissism," an actual historical event in the person's history. It is possible to read Freud's theory from a particular perspective which sheds light on the meaning of schizophrenia in our particular cultural-historical epoch, and furthers our understanding of Schreber and his quest for justice in the restoration of the "Order of the World."

Summarizing Freud's understanding of the loss of reality in psychosis, De Waelhens (1972) writes: 
One could present the distinction of neurosis and psychosis by saying that if the neurotic represses the unconscious or the id under the pressure of reality and on behalf of the latter, the psychotic does the opposite. Under the influence of the 'id' the psychotic retrieves his investments of reality to attach them to himself and thus, in a certain way, represses this reality. (p. 112)

This is a peculiar way of talking about psychosis, which largely defines psychosis in terms of a lack; he or she lacks the reality principle which represses id impulses, and instead represses the real rather than the id. It would be easy to simply dismiss Freud's theory as doing an injustice to the schizophrenic by defining him or her in terms of a lack. However, it is more informative, and frankly more interesting, to try to explore how this understanding of schizophrenia makes sense given the culturalhistorical context. This rigid distinction between neurosis and psychosis hinges on a particular form of psyche-world dualism which is culturally and historically specific to our age. Such a categorical distinction belongs to a world in which "truth" is only appreciated as the distant gaze of "objectivity" and "subjective" conscious experience is understood to be epiphenomenal. It is a world which then places all those categories which do not fit the "truth" of objectivity on the other side of the pole. Not just madmen, but poets, mystics, children and primitives serve as the others of the one, Western, "objective" consciousness so that it can maintain its self-same identity as the "one." To begin to differentiate these others (primitives, mystics, the mad, children, etc.) can begin, first, with recognizing what they have in common. In each case, such a style of being is more participatory, a world where "truth" is measured not by the distant gaze of the modern scientist as much as by what Pascal called the "reasons of the heart." By first exploring how the schizophrenic is very much like the child, the primitive, or the poet is to begin to differentiate them as other, legitimate ways of being in the world.

What is peculiar about the experience of the schizophrenic, Schreber in particular, is this so-called shift in direction of 'libidinal energy.' The psychotic, as fixated at the narcissistic stage or "primary repression" is much like the child who has yet to differentiate him or herself from the world of the mother. He or she is fused with the world around her. It is not that the child thinks and feels only for him or herself; instead, it is he or she who sees him or herself reflected in the world. This is the world prior to the emergence of the "specular I" of which Lacan (1949) has spoken. That Freud sees a connection between this "narcissism" of the infant-child and the schizophrenic is significant, though not for the explication of the adult schizophrenic's repression of homosexual 
libido. Rather, the schizophrenic appears to share with the child, as do the mystics, what seems to be an undifferentiated fusion with the world. By understanding this connection between the child, mystic and the mad, it becomes possible to understand how such a participatory consciousness in our culture, for the adult, can become madness, as opposed to shamanism or mysticism. Such an undertaking, however, requires a broader, cultural-historical perspective. To understand the magnitude of the schizophrenic's suffering we must understand his or her place in history.

Hillman (1975) marks a trend beginning in the Christian and Cartesian views in the 15th century which eventually led toward the relegation of imagination (what he calls "personifying") to children, primitives, mystics and the mad. For Hillman, the incarnation of this movement is embodied by Marin Mersenne (1588-1648). Mersenne was an avid campaigner for Descartes and Galileo, as well as a veracious opponent of anything having to do with magic and the occult, including alchemy and any form of animism or Hermeticism. Berman (1989) sums up Mersenne's thought as a general tendency "to resolve miraculous, occult and religious issues in mechanico-mathematical terms" (p. 240). As Hillman (1975) argues, Mersenne's vision succeeded in exiling the imaginal from the population.

Mersenne's vision has been realized in our age, although probably much differently than he had intended. We live the legacy in which Church Aristelianism shifted toward modern science - not as "a shift to an age of reason, as has so often been said, but from an age of one faith to an age of another faith" (Berman, p. 249). Yet modernity retains the ascent structure of the Church, though in a secularized version. No longer inclined to believe in a "spiritual ascent," the modern, industrial world resorts to "modern equivalents of the equations and methodology developed by Newton and Galileo to make the ascent to the heavens in a direct, material way" (Berman, p. 249). This insight is echoed in Romanyshyn's (1989) brilliant interpretation of modern humankind as Homo astronauticus seeking to escape death by simultaneously escaping earth by penetrating into space and vacating the corpse-like body of modern science through technology.

Van den Berg (1961) discovers a similar phenomenon in his discussion of miracles. In the understanding of Mersenne's vision, one can see that it appears to conform to van den Berg's discussion of the belief in miracles as "spoiled nature" (p. 201). Miracles as "spoiled nature" occur when miracles are explained in terms of natural science. Descartes exiled God to a position in which $\mathrm{He}$ is understood as first cause, thus 
God is relegated to a distant past, removed from the world of everyday human beings. For van den Berg, if God is to reappear within the Cartesian view of reality, "which has become foreign to him, in the shape of an 'objective' fact among other 'objective facts,' then this means that God dies" (p. 201).

The Cartesian world view supported by Mersenne understands a world in which miracles can no longer occur. God has been removed to a distant past in which "distance" pervades the world. "Truth" is that which is held at a distance - the "objective" view, which Romanyshyn (1989) traces back to the emergence of linear perspective in painting as early as 1435 with Leon Battista Alberti (p. 35). The shift in worldview from pre-modern to modern, for van den Berg, is a shift in spatiality toward an increased distance. As van den Berg (1961) writes: "Future and past have become invisible; the present is in a tremendous hurry to pass us. The child today is far away from adults; adults have less real mutual contact. But all these increased distances are reflections of but one single one: the increased distance of God" (pp. 190-191).

The kind of participatory engagement with the world which is often associated with children, primitivity, mysticism and madness is evident in Piaget's (e.g., 1955, 1967, 1977) description of the world of the child. Johnson (1996), in fact, argues that Piaget's conception of the "childas-primitive" fosters the separation between adult and child, a phenomenon peculiar to modern culture. She asserts that, as a consequence, the relationship between adult and child is impaired, resulting in, for example, "patronizing conversations" and parents' reliance on "the assistance of psychological experts" to make sense of their children (p. 37). Johnson notes: "The child-as-primitive analogy rests on an implicit teleological assumption that what we know as adult, Western consciousness is the natural, inevitable, and most desirable end to development" (p. 37). What children, primitives, mystics and the mad have in common, it follows, is a deviation from this adult, Western consciousness. According to the Piagetian model, such an "adult" consciousness is characterized as "formal operations." As Rybash, Hoyer, and Roodin (1986) note, there is an implicit weakness in "formal operational" thinking. Namely: Formal thinking is only suited for the problems that call for scientific thinking and logical mathematical analysis. In other words, "formal" thinking conforms to the rational worldview of Descartes espoused by Mersenne and exemplified by Newtonian physics.

Formal thinking is the rational thought which places itself at a distance from the lived world, a second order abstraction which, in Western consciousness, becomes the "real" world. Starting with this perspective, 
Freud's understanding of the psychotic can be seen in a different light. While the neurotic represses the lived world of participatory engagement with things and others, the psychotic rejects, not the "real" world, but the world of abstraction. What the neurotic represses, the psychotic lives, and, on this point, Freud is correct: Schreber's text can be read on the surface, because what he tells us is not censured by the egoconsciousness of our culture. As Berman (1996) writes:

... a major part of the psychotic experience is the return to the perception of the world in Hermetic terms. That madness is the best route to perception I tend to doubt; but the fact that madness triggers the premodern epistemology of resemblance does suggest that the insane are onto something we have forgotten, and that (cf. Nietzsche, Laing, Novalis, Hölderlin, Reich...) our sanity is nothing but a collective madness. (p. 131)

To genuinely understand Scheber in his difference, however, it is not enough to simply equate his experience with all those marginalized others who, by being negated as lack by Western consciousness, permits Western rationality to maintain self-sameness. What makes Schreber and others like him appear mad is that he does not have the words at his disposal to bring his message to the world. Instead, he is forced to translate his experience into rational, Cartesian language and seeks proof in natural science. As a result, his "miracles" become "spoiled nature," the product of a dead God who is merely the result of his "delusions." Moreover, Schreber becomes, as a result, identified with the hero archetype. This is the source of his belief that "everything that happens is in reference to me" (Schreber, 1903, p. 197). That is, Schreber identifies with the hero archetype of the "encapsulated ego" (Boss, 1979), "selfcontained individual" (Sampson, 1988), or "heroic ego" (Hillman, 1975), call it what you will. Ironically, it is this very notion of the "ego" as self-same identity which renders "what does not fit in" as "inhuman, psychopathic, or evil" and provides the possibility for his insanity. Instead of a recognition of the anima mundi, the soul-full world that he comes to experience through "miracles," Schreber instead envisions the absorption of all the world into him, thus becoming an inflated stereotype of the "heroic ego" at its extreme. He becomes an embodiment of the shadow-side of the "self-contained individual," like the exaggerated, painted-on expression of a clown that marks him as a joke, calling attention to his own ridiculousness.

In a way that is similar to Deleuze and Guattari's (1983, 1987) understanding of schizophrenia, as opposed to schizoanalysis, Schreber's endeavor to become otherwise can be understood as a valiant though failed project. In the terminology of Deleuze and Guattari (1987), 
Schreber can be understood as having manufactured a failed "BwO" or "Body without Organs," which Deleuze and Guattari call an "empty BwO." In his attempt to "map a line of flight" and thereby "destratify" conventional formations of "strata," Schreber goes too far too quickly and, rather than finding liberation, he becomes mad.

You have to keep enough of the organism for it to reform each dawn; and you have to keep small supplies of significance and subjectification, if only to turn them against their own systems when the circumstances demand it, when things, persons, even situations, force you to; and you have to keep small rations of subjectivity in sufficient quantity to enable you to respond to the dominant reality. Mimic the strata. You don't reach the $\mathrm{BwO}$, and its plane of consistency, by wildy destratifying. (Deleuze and Guattari, 1987, p. 160)

Yet, at the same time, Schreber does not entirely fail. He does, after all, win back his freedom, and he writes his memoirs. This essay is a testament to Schreber's potential impact to touch us if we open ourselves to his message. There is a sense in which Schreber's success or failure does not so much hinge on him, but depends upon our reception of his tale. While Schreber becomes a living representative of the masculine, heroic ego in the extreme, we are not bound to view this as his failure. Like the clown who mirrors our own absurdities through parody, Schreber mimics the "heroic ego" and thereby amplifies it to the point of ridiculousness. Schreber is restored to health, in the end, not because he takes up the masculine, Western consciousness of his day; on the contrary, he gains his freedom through his "unmanning." From this perspective, Schreber does not create an "empty BwO," but instead, in keeping with Deleuze and Guattari's language, finds liberation by "becoming-woman." With the assistance of Irigaray, it is possible to interpret Schreber's recovery as a shift from a psychotic mode, in which he falls into a space of undifferentiated fusion, to a more feminine consciousness, via his acceptance of the "unmanning" process, which allows him to recognize his difference.

Influenced by Lacan, Irigaray asserts that the masculine symbolic is secured by the phallus which, as elaborated in Lacan's theory, is premised on Woman as "lack." Such a "specular logic," in Irigaray's (1985a) terms, reduces the other to the logic of the same. Yet, Irigaray asserts, when women bring their bodies out of silence and servitude, the masculine subject can no longer live with the illusion that he is self-contained and whole over against her lack. As Lorraine (1999) writes: "the contemporary masculine subject reflects himself onto a feminine other in order to affirm himself repeatedly as a self-identical and self-sufficient 
subject" (p. 103). For Irigaray, the recognition of sexual difference depends on an articulation of difference which does not posit the other as the other of the "one" flesh, but re-imagines flesh as the site from which both men and women emerge in their difference.

When the feminine is symbolized, men can discover that there is a "place for love" because flesh does not threaten with the diffusion of subjectivity but provides a "third term" which can act as an intermediate ground between the two, allowing for an identity-in-difference rather than a reduction of the other to the same (Irigaray, 1993, p. 27). In mutual recognition of difference, however, there would not be a reification of the other in her difference, but a creative interchange of the two which would be fluid rather than fixed, like mucous (Irigaray, 1993).

By embarking on his project of "unmanning," Schreber can be understood as striving to be otherwise than his previous existence as a selfsame masculine subject. Irigaray's project is similar to Schreber's in that she symbolizes feminine difference in such a way that it opens up a place for what she calls the "sensible transcendental": A place which, in a sense, is no-place in particular but a region which is a transcendence-in-immanence. Unlike the religion of the masculine economy which separates the flesh from spirit, the "sensible transcendental" is a divine which does not remove us from corporeality, but discovers divinity in the depths of the flesh.

Appropriately, Irigaray finds examples of this "sensible transcendental" at play in the work of some mystics. Mystical language is unique in that it attempts to give expression to the ineffable. The mystic senses that "something remains to be said that resists all speech, that can at best be stammered out" (Irigaray, 1985b, p. 193). The mystic recognizes that the experience of the same does not reveal the mystery of life. By breaking out of the "prison of self-sufficiency" of the masculine economy (p. 192), she or he risks losing self-same identity in order to genuinely touch another in differentiated contact. Yet, while the mystic risks losing her or his self-same identity by delving into the depths of flesh, she or he is not dismembered, but discovers there a different kind of unity, a relentless immediacy which is "not nothing" (p. 193). Rather, "the mystic achieves an awareness informed by what lies beyond all representations of a deeper unity which takes no stable form as its reference" (Lorraine, 1999, p. 74).

Schreber's experience is reminiscent of Irigaray's call for both a different religiosity and a different way of being gendered. Irigaray's "sensible transcendental" recalls van den Berg's notion of the miraculous, lived world which, with the distant gaze of objectivity, becomes 
repressed. Such distance is the sign of a distant God. It is Schreber's experience of this distant God which provides a context for his task. Schreber sees his body brimming with "soul-voluptuousness." $\mathrm{He}$ is, all at once, experiencing the eruption of what van den Berg calls the "spiritual unconscious": the sensuous lived world exiled with the imaginal via the Cartesian worldview, which is closely aligned with Irigaray's "sensible transcendental." And Schreber experiences this as God's presence moving closer to the world! Schreber's experience is the "narcissistic" experience of the infant-child-for it is in the experience of the infant-child that lived, participatory engagement and the imaginal have been displaced by the rational, modern adult. And it is such a participatory engagement that the child shares with, while living such participation in a way that is structurally different from all those marginlized others by which modern, Western consciousness maintains its identity. Seen in this light, Schreber's message becomes clear. The restoration of the "Order of the World" requires a renewal of the world. For the first time in thousands of years, he exclaims, "miracles" are again possible, for God has returned to the world! And it is with this revelation that Schreber begins his return from his "journey" with his message for the world.

As Irigaray (1991) writes, if word is to truly be "made flesh," we must imagine a divine god which "does not simply rule the world from the heaven of dreams, and does not remain in a text of closed law either" (p. 181). Like Irigaray's "unmanning" of religiosities within the masculine economy with her notion of the "sensible transcendental," Schreber's soulful spirituality is the cultivation of a divine flesh, which is "both more spiritual and more carnal at the same time" (p. 24).

Schreber's peak of psychosis is characterized by his mimicry of the "heroic ego," but, when he returns to the world of the living spilling over with "soul-voluptuousness," he comes to the brink of a recognition of difference. He shifts toward a way of being which is closer to Irigaray's ethics of the sensible transcendental, which does not reduce the other to the logic of the same. When he is touched by his wife's poem, he encounters her as other and this moment in Schreber's story marks a profound turning point for him. Shortly thereafter he would regain sense enough to begin fighting for his liberty. To make his return, Schreber can no longer live the delusion of Freud's "primary repression," but must come to the realization that the alterity of the other is not a dissolution of identity into the other. His encounter with the other must become, instead, a "positive alterity" (Lorraine, 1991, p. 98). Schreber, unfortunately, did not go far enough in his encounter with the other, his wife, in her difference, for he continues to imagine that 
she will be dissolved into his body. Had he come to a full recognition of her difference, would he have made the shift from mere madness to a not-quite-mad poet-visionary?

Irigaray, beyond Schreber, can help us to discover a being otherwise which escapes the dichotomy between madness as a regression to primary narcissism and neurotic repression of the lived. With Freud and Lacan, Woman is figured as lack by way of retroactive performativity in phallic discourse as an effect of castration (Cornell, 1998). Thus, masculine, phallic discourse as Oedipal is predicated upon, as Irigaray asserts (1993), "an even more ancient murder, that of the woman-mother" (p. 11). The Oedipal ambivalence toward the father is "projected retroactively upon the primitive relation to the mother's body," such that partial drives "seem to refer especially to the body that brought us whole into the world" (p. 13).

To return with fertile language to the flesh of the world without fear of being swallowed by an undifferentiated abyss, we must speak a kind of poetic discourse which frees the mother from phallic retroactivity. Schreber, as mentioned previously, unfortunately lacked this language; instead he resorted to the language of natural science. However, by returning to a poetics of intrauterine experience, Irigaray gives language to the experience of the womb which is no longer a language of nondifferentiation and fragmentation, but discovers there a reversibility between mother and fetus which is already in place. Before the phallus, there was the umbilical cord. Irigaray (1993) writes:

All that had taken place within an originary womb, the first nourishing earth, first waters, first sheaths, first membranes in which the whole child was held, as well as the whole mother, through the mediation of her blood. According to a relationship that is obviously not symmetrical, mother and child are linked in a way that precedes all dissociations, all tearing of their body to pieces. (p. 14)

Only later will this whole mother who cradles the child in her womb be shredded into part objects by the retroactive performativity of castration, by which she will be made into partial, phallic drives. Yet, this is not a place for return, for return is not possible. As Irigaray (1993) writes, "All kinds of veils may claim to take its place, seek to repeat it, but there can be no return to that first dwelling place" (p. 81).

The masculine nostalgia of returning to the womb-likely a nostalgia shared by Schreber - is that death wish which has forgotten that, in the womb, mother was already other, already alterity, because of the veil of the placenta which separated us yet kept us connected to one another, like Merleau-Ponty's (1973) chiasm of flesh. While the psy- 
chotic dissolves into undifferentiated contact, the mystic and visionary, even while risking such dissolution and losing self-same identity, discover how to genuinely touch another in differentiated contact. In this sense, Irigaray's mystic as "sensible transcendental" is neither psychotic nor neurotic in Freud's sense of these terms. While the psychotic becomes lost in undifferentiated fusion and the neurotic remains stuck in the selfsame identity of specular logic, the mystic encounters that mucous of ambiguity by which she or he discovers him or herself, as an embodied sensible transcendental, in a process of continuous emerging, touching upon new ground. The person who attains the sensible transcendental attains "the material texture of beauty. He would have 'seen' the very spatiality of the visible, the real that precedes reality, all forms, all truths of particular sensations or constructed idealities" (Irigaray, 1993, p. 32).

That Schreber ultimately had difficulty encountering others as others is not in the least helped by those who encounter him. As radically other in his madness, Schreber's difference is only recognized as that bizarre abnormality which, as lack and mal-adjustment (like woman, child, primitive), is used to keep the masculine economy within its selfsame identity. Schreber's demand for justice is not mere delusion, but has an existential truth. Is not Schreber suffering a grave injustice? He offers the world the gems of his experience, and the world turns its head in disgust. Schreber is not a shaman, but a madman. He does not exist in a world which can guide him through the lived world in which he finds himself. Instead, he is placed in asylums. It is Flechsig and von W. who he marks as his "only true enemies" (1903, p. 55). And why shouldn't they be? Do they not indeed commit "soul murder" against Schreber? Flechsig and von W. do not intend to help him along the way - to assist his pass through the "dark night of the soul" in order to find his way back to genuine encounters with others. They seek to cure him and thereby keep Schreber from his task. It is Flechsig who orders Schreber to be placed in a rubber room in the dark and later denies it ever happened. And it is Flechsig who orders Schreber's windows to be boarded up so that he cannot search the stars for his God and "tested souls." It was von W. who gave "false evidence" about Schreber "in some State enquiry, either on purpose or through carelessness, and particularly to have [him] accused of masturbation" (p. 107). It was these men who set the attendants of the asylum against Schreber to "take control of [his] body" (Schreber, 1903, p. 110). Are these mere delusions of persecution, as well? Or does Schreber speak the truth of his world? What to all outward appearances must have seemed the best intentions from Flechsig and von W. to heal Schreber, 
to Schreber himself it is the work of evil, a plan to undermine the "Order of the World." And now that we've peered into Schreber's world, can we deny him this truth?

Most importantly, Schreber's quest for a restoration of the "Order of the World" is, in the final analysis, a quest for justice - and not just for himself, but for the entire order. He suffers, and he comes to believe that he will be justly rewarded for his pain. In the end, Schreber is indeed Senatspräsident, yet no longer of Dresden, but of the "Order of the World," who deems that nothing which usurps that "order" can survive in his universe.

Schreber, after all, has something profound to teach clinicians. To speak of Schreber with "psychiatric jargon" is to speak the language of psychiatry which, as Laing (1960) asserts, "is the effort to avoid thinking in terms of freedom, choice and responsibility" (p. 27). This language, according to Laing, consistently describes madness as a form of lack or mal-adaption. Similarly, van den Berg (1972) critiques psychiatry's "vocabulary of denigration" which makes the patient a victim of the "closer look" in which the phenomena of the patient's existential condition are missed "as they are" (p. 63). In Laing's example of Kraepelin in The Divided Self, Kraepelin's failure to understand the patient is his primary mistake. Kraepelin was so busy analyzing the patient's behavior as "signs of disease" that he forgot the patient was, first and foremost, a human being like himself. As Laing writes: "If someone is on the other side of an abyss, he doesn't cease to be a human being" (Kirsner, 1996, p. 59).

In refraining from psychiatry's "vocabulary of denigration" with this reading of Schreber, we have endeavored to read Schreber with love, on his own terms, with a recognition of his difference as another human being who suffered. In taking the time to read the logos of his pathosthe meaning of his suffering - we have learned from Schreber. He has taught us a way of being that is otherwise. He has anticipated Irigary's "sensible transcendental" and foresaw the need of his age for a closer God and participatory engagement with the world, marginalized with the Cartesian worldview. By his experiment with "unmanning," he risked all to find a way of being that is other than the masculine, specular logic which Irigaray critiques. He has shown us that, if we clinicians are to heal rather than further injure, we must find ways to assist rather than thwart the breakthrough of psychosis onto a new, more differentiated plane of existence. In Irigaray's (1991) words, Schreber has shown us the possibility for "the coming of a reality that is alien to an already- 
existing identity" (p. 171). Listening closely rather than at a distance, we find that Schreber has given us the gift of his difference. While Schreber died long ago, his legacy remains. It is hoped that having encountered Schreber's story, we may learn better how to encounter those, still living, who are very much like Schreber, who still lie dormant with a message we might discover if we only have the ears to hear it.

\section{REFERENGES}

Berman, M. (1981). The reenchantment of the world. Ithaca \& London: Cornell University Press.

Berman, M. (1989). Coming to our senses. New York: Bantam Books.

Boss, M. (1979/1994). Existential foundations of medicine and psychology. Northvale, NJ: Jason Aronson.

Breuer, J. \& Freud, S. (1895/1966). Studies on hysteria. New York: Collier.

Campbell, J. (1972). Myths to live by. New York: Viking Penguin.

Chabot, C. (1982). Freud on Schreber. Amherst: The University of Massachusetts Press.

Cornell, D. (1998). Rethinking the beyond of the Real. In S. Harasym (ed.), Levinas and Lacan: The missed encounter. Pp. 139-181. Albany: State University of New York Press.

De Waelhens, A. (1972). Schizophrenia. (W. Ver Eecke, trans.). Pittsburgh: Duquesne University Press.

Deleuze, G. \& Guattari, F. (1983). Anti-Oedipus: Capitalism and schizophrenia. (R. Hurley, M. Seem, \& H. R. Lane, trans.). Minneapolis: University of Minnesota Press.

Deleuze, G. \& Guattari, F. (1987). A thousand plateaus: Capitalism and schizophrenia. (B. Massumi, trans.). Minneapolis: University of Minnesota Press.

Freeman, M. (1998). The wide-spun moment: Ecstasy and madness in Celtic tradition. Parabola, 23(2), 29-35.

Freud, S. (1904). On psychotherapy. In Therapy and technique. (P. Rieff, ed.). New York: Collier.

Freud, S. (1905/1963). Dora: A fragment of an analysis of a case of hysteria. New York: Collier.

Freud, S. (1909a/1966). The sexual enlightenment of children. New York: Collier.

Freud, S. (1909b, 1911, 1918/1963). Three case histories. New York: Collier.

Heidegger, M. (1926/1962). Being and time. New York: Harper \& Row.

Heidegger, M. (1971). On the way to language. (P. Hertz, trans.). New York: Harper \& Row.

Hillman, J. (1975). Re-visioning psychology. New York: Harper \& Row.

Irigaray, L. (1985a). Speculum of the other woman. (G. C. Gill, trans.). Ithaca: Cornell University Press.

Irigaray, L. (1985b). This sex which is not one. (C. Porter \& C. Burke, trans.). Ithaca: Cornell University Press.

Irigaray, L. (1993). An ethics of sexual difference. (C. Burke \& G. C. Gill, trans.). Ithaca: Cornell University Press.

Irigaray, L. (1996). I love to you: Sketch for a felicity within history. (A. Martin, trans.). New York: State University of New York Press.

James, W. (1961). The varieties of religious experience. New York: Collier.

Johnson, A. (1996). Constructing the child in psychology: The child-as-primitive in Hall and Piaget. Journal of phenomenological psychology, 26(2), 35-37.

Kirsner, D. (1996). The human condition: An interview with R. D. Laing. Psychotherapy in Australia, 2(4), 55-60. 
Lacan, J. (1949). "The mirror stage as formative of the function of the I as revealed in psychoanalytic experience." In J. Lacan (1977). Ecrits. (A. Sheridan, trans.). New York: W. W. Norton.

Laing, R. D. (1967). The politics of experience. New York: Pantheon Books.

Lorraine, T. (1999). Irigaray and Deleuze: Experiments in visceral philosophy. Ithaca \& London: Cornell University Press.

Lothane, Z. (1993). In defense of Schreber: Soul murder and psychiatry. Analytic Press.

Merleau-Ponty, M. (1973). The visible and the invisible. (C. Lefort, ed. \& A. Lingis, trans.). Evanston: Northwestern University Press.

Piaget, J. (1955). The language and thought of the child. Cleveland: World Publishing.

Piaget, J. (1967). The child's conception of the world. Totowa: Littlefiend, Adams.

Piaget, J. (1977). The essential Piaget. Northvale: Jason Aronson.

Romanyshyn, R. (1989). Technology as symptom and dream. London \& New York: Routledge.

Rybash, J., Hoyer, W. \& Roodin, P. (1986). Adult cognition and aging: Developmental changes in processing, knowing and thinking. New York: Pergamon.

Sampson, E. (1988). The debate on individualism. American Psychologist, January 1988.

Schreber, D. (1903/1955). Memoirs of my nervous illness. (I. Macalpine, trans. \& ed.). London: Wm. Dawson \& Sons.

Silverman, J. (1967). Shamans and acute schizophrenia. American anthropologist, 69(1).

Szasz, T. S. (1997). The manufacture of madness: A comparative study of the inquisition and the mental health movement. Syracuse: Syracuse University Press.

Van den Berg, J. H. (1961). The changing nature of man. New York \& London: Routledge.

Van den Berg, J. H. (1972). A different existence. Pittsburgh: Duquesne University Press. 
Copyright of Journal of Phenomenological Psychology is the property of Brill Academic Publishers and its content may not be copied or emailed to multiple sites or posted to a listserv without the copyright holder's express written permission. However, users may print, download, or email articles for individual use. 